УДК 658.1

https://doi.org/10.33296/2707-0654-9(18)-08

\title{
МУШНИКОВА СВІТЛАНА
}

кандидат економічних наук, доцент, Національна металургійна академія України, м. Дніпро, Україна

ORCIDiD: https://orcid.org/0000-0002-3860-522X

\section{КОРСАКОВ ДМИТРО}

кандидат економічних наук, доцент, Українська інженерно-педагогічна академія, м. Харків, Україна ORCIDiD: https://orcid.org/0000-0001-5223-7286

\section{МОТИВАЦІЙНИЙ МЕХАНІЗМ УПРАВЛІННЯ ЕКОНОМІЧНОЮ БЕЗПЕКОЮ ПІДПРИЄМСТВ}

\begin{abstract}
Анотація. Сьогодення характеризуються кризовими ознаками, які спостерігаються тривалий час в національній економіці. В результаті дослідження визначено, що в сучасних умовах трансформаційних перетворень національної економіки, підприємства стикаються з рядом проблем, пов'язаних, в тому числі, й 3 управлінням їх економічної безпеки. Тому потрібен мотиваційний механізм управління економічною безпекою підприємств, як комплекс дій, спрямованих на формування умов для досягнення захищеного стану розвитку підприємства в процесі адаптації до трансформацій в просторі та часі. Центральним функціональним елементом в системі управління економічною безпекою підприємства виступає мотивація, яка спонукає планувати та організовувати види його діяльності на досягнення захищеного стану розвитку підприємства 3 отриманням позитивних економічних показників.
\end{abstract}

Наряду 3 загальнонауковими принципами управління економічною безпекою підприємств, такими як: цілеполягання; керованість процесом управління; актуальність; системність; науковий підхід; - в ході дослідження визначено принципи, які притаманні мотиваційному механізму управління економічною безпекою підприємства, а саме: принцип безперервності управління, циклічності, адекватності, гнучкості системи управління економічною безпекою підприємства та ін.

Доведено, що найбільш дієвими інструментами мотиваційного механізму управління економічною безпекою підприємств в сучасних умовах $\epsilon$ загальнодержавні. Поєднанням інструментів підприємницької діяльності таких, як: креативність мислення; інноваційність системи управління; адекватна 
Електронне наукове фрахове видання «Адаптивне управління: теорія і практика»

Серія «Економіка»

Випуск 9 (18), 2020

інформаційність системи управління; доступна цифровізація управління, - 3 державними інструментами мотиваційного механізму управління економічною безпекою підприємств, можна досягти певного розвитку їх інноваційної діяльності.

Ключові слова: економічна безпека, управління, підприємство, механізм управління, мотиваційний механізм управління.

Вступ. Сучасні умови функціонування підприємств, а саме: зростання фінансової залежності від держави, недосконалість нормативно-правової бази, втрата податкових пільг окремих 3 них, зниження рівня конкурентоспроможності внаслідок невідповідності якості продукції та підвищення рівня витрат, втрата ринків збуту продукції та послуг та багато ін., - характеризують кризові ознаки, які спостерігаються тривалий час в національній економіці.

3 іншої сторони, зміна індустріального етапу розвитку економіки на постіндустріальний, призвели до значної втрати промислової продукції через скорочення діяльності промислових підприємств, та, навіть, втрати деяких галузей національної економіки. Внаслідок цих факторів відбулося зниження обсягів ВВП майже втричі протягом останніх двадцяти п’яти років.

Це обумовлює необхідність вивчення питання управління економічною безпекою підприємств з точки зору їх мотивації до розвитку, із виокремленням існуючих та можливих дієвих інструментів.

Аналіз останніх публікацій i досліджень. Питання управління економічною безпекою всіх рівнів національної економіки, в тому числі й підприємств, привертає увагу великої кількості як вітчизняних, так й закордонних науковців. 3 часу становлення ринкових відносин та 3 посиленням значення протидії різного роду зловживань й шахрайства, все більша кількість вітчизняних та закордонних науковців займаються окремими питаннями управління безпекою різних суб'єктів й, безпосередньо, економічною безпекою як однією із іiі складових $[1,6,8,9]$. Зокрема, останнім часом багато робот присвячено дослідженням науковців стосовно механізмів управління різними 
Електронне наукове фрахове видання «Адаптивне управління: теорія і практика»

Серія «Економіка»

Випуск 9 (18), 2020

видами діяльності промислових підприємств таких, як: фінансовою, інвестиційною, інноваційною $[1,4,5,7]$.

Метою статті $є$ теоретичне обгрунтування формування мотиваційного механізму управління економічною безпекою підприємств в трансформаційних умовах господарювання.

Виклад основного матеріалу. Загрози та ризики зовнішнього характеру впливу на діяльність окремих підприємств викликають загрози внутрішньої дії, провокуючи поглиблення кризових явищ у всіх сферах його життєдіяльності, охоплюючи виробничу, технологічну, соціально-трудову, фінансову та інші підсистеми, та призводить до деградаційних процесів. Наслідком цього є погіршення макроекономічних показників, порушення збалансованості фінансової системи, зростання рівня інфляційних процесів, зниження пропозицій на ринку праці, i, як наслідок, зниженням рівня життя населення, загостренням соціальних конфліктів, що, в свою чергу, впливає на рівень конкурентоспроможності.

Процеси деградації в діяльності окремих підприємств характеризуються як фактор переходу від епохи індустріалізації на постіндустріалізацію, та спричинені багатьма факторами, серед яких можна виділити наступні [9]:

- застарілістю техніки та технологій, які функціонують ще 3 періоду індустріалізації, із зменшенням долі промисловості у напрям збільшенням сфери послуг;

- низький рівень конкурентоспроможності вітчизняних підприємств, обмеженість, або повна відсутність, інноваційних впроваджень 3 недостатнім рівнем їх інвестування;

- застарілість принципів, ієрархічної структури, методів управління підприємствами, що викликає обмеженість або повну неспроможність його адаптації в трансформаційному середовищі;

- неефективна податкова система, яка зумовлює зростання податкового навантаження на діючи підприємства в міру нарощення їх доданої вартості; 
Електронне наукове фрахове видання «Адаптивне управління: теорія і практика»

- слабкий захист вітчизняних товаровиробників та/або відсутність державної підтримки щодо сприяння просування високотехнологічних товарів національного виробництва на світові ринки.

Процеси, які стали перепоною для розвитку підприємств в трансформаційних умовах господарювання під впливом загроз та ризиків, в основному, зовнішнього середовища, спричинили зниження спроможності управляти економічною безпекою окремих підприємств.

Перелічені фактори визначили передумови для формування мотиваційного механізму управління економічною безпекою підприємств (рис.1). Так, недосконалість податкової системи в Україні, із зростанням податкового навантаження на діючи підприємства в міру нарощення їх доданої вартості, призвело до зростання «тіньової» економіки та різкого погіршення стану державних фінансів.

Результатом недосконалості грошово-кредитної політики центрального банку країни стало погіршення якості ресурсної бази та кредитних портфелів банків через перевагу споживчого кредитування, збільшення рівня боргових зобов’язань на тлі зростання вартості запозичень, та, навіть, відсутністю інвестиційного кредитування підприємств. Це, в свою чергу, вплинуло на інноваційно-інвестиційну активність підприємств та погіршення їх конкурентоспроможності як на вітчизняному, так й на світовому ринках. Відбувається диспропорція між виробництвом і споживанням. Споживання вийшло за межі можливостей національного виробництва, що призвело до значного зростання імпорту, диспропорції між імпортом і експортом (про це свідчить від'ємне сальдо зовнішньоторговельного балансу країни), та кількості іноземної валюти в країні, що напряму впливає на курс гривні і швидкість інфляційних процесів [1]. 
Електронне наукове фрахове видання «Адаптивне управління: теорія і практика»

Серія «Економіка»

Випуск 9 (18), 2020

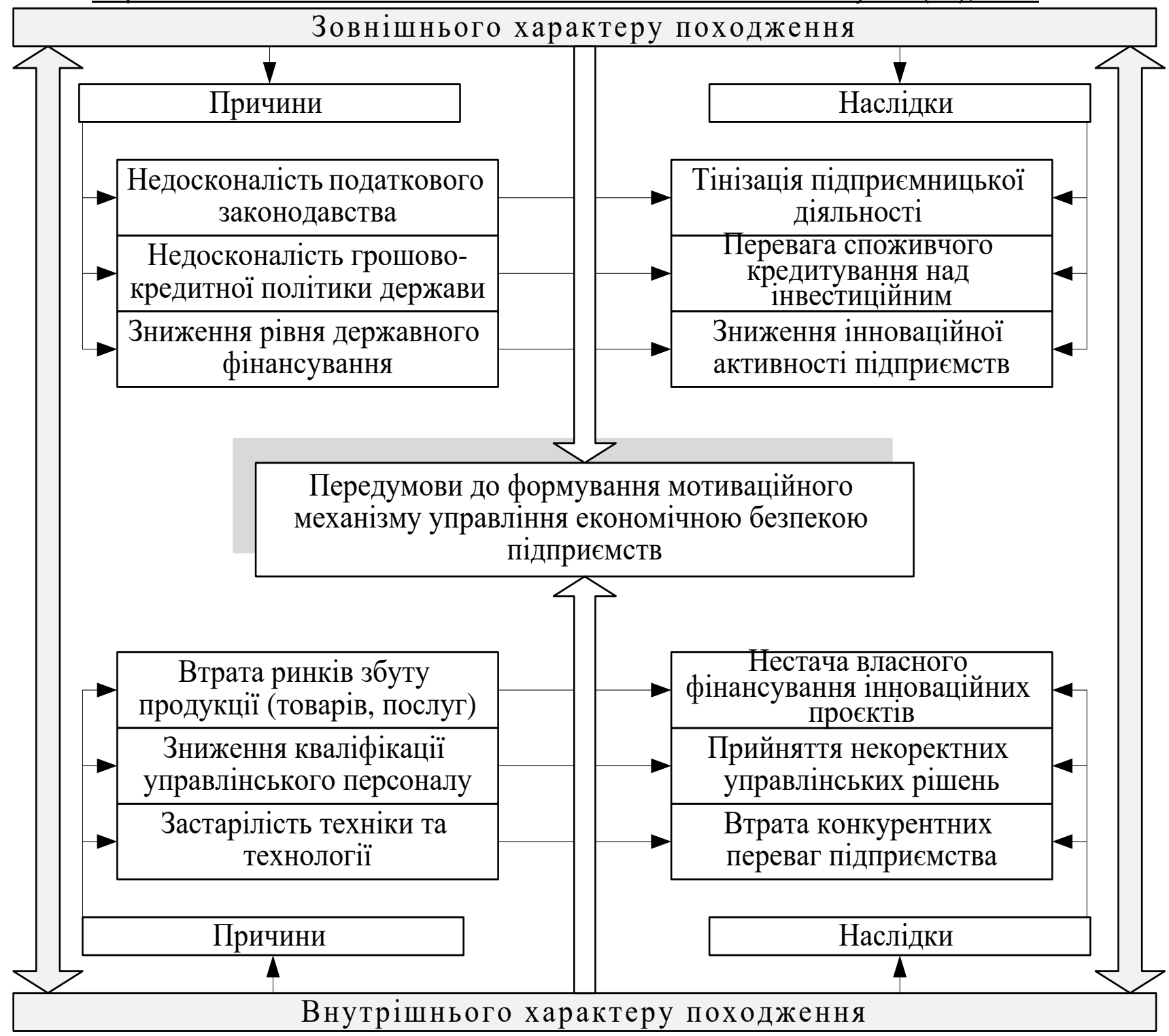

Рис. 1. Передумови до формування мотиваційного механізму управління економічною безпекою підприємств

За визначенням нобелівського лауреата Дж. Хікса, сучасний етап трансформаційних перетворень являє собою «адміністративну революцію», сутність якої проявляється у зростанні економічної ролі держави в діяльності підприємств. Цей факт відзначений вітчизняними науковцями, які розглядають «адміністративну революцію» як складову частину економічних революцій кінця XX століття. Сутність цього поняття розкривається як: радикальні якісні організаційно-управлінські трансформації, які стали наслідком та одночасно 
Електронне наукове фрахове видання «Адаптивне управління: теорія і практика»

фактором технологічної, структурної, інформаційної революцій, та в сукупності призвели до інституційної трансформації Західного суспільства [10], та покладено в основу формування мотиваційного механізму управління економічною безпекою підприємства.

Економічною основою поняття «механізм» $€$ функціонування цілісної системи економіки та розглядається як сукупність проміжних станів чи процесів будь-яких економічних явищ. Окремі автори визначають сутність механізму управління як поєднання понять «механізм» та «управління». Таке узагальнення дає можливість зробити висновок, що під механізмом управління підприємством слід розуміти цілеспрямовану сукупність дій, які базуються на концептуальних принципах його функціонування, цілях i функціях, 3 використанням відповідних методів та інструментів управління, спрямованих на забезпечення позитивних трансформацій підприємства у теперішній час та майбутньому [3, 7].

Кінцевим результатом дії будь-якого механізму управління, зокрема, управління економічною безпекою підприємства, $є$ вплив на процес розробки та реалізації оптимальних управлінських рішень щодо захисту його господарських інтересів з урахуванням особливостей його діяльності, що забезпечує зростання ринкової вартості підприємства на основі використання інноваційного управлінського апарату стратегічного характеру.

Основні структурні елементи мотиваційного механізму управління економічною безпекою підприємств представлені на рис. 2. 
Електронне наукове фрахове видання «Адаптивне управління: теорія і практика» Серія «Економіка» Випуск 9 (18), 2020
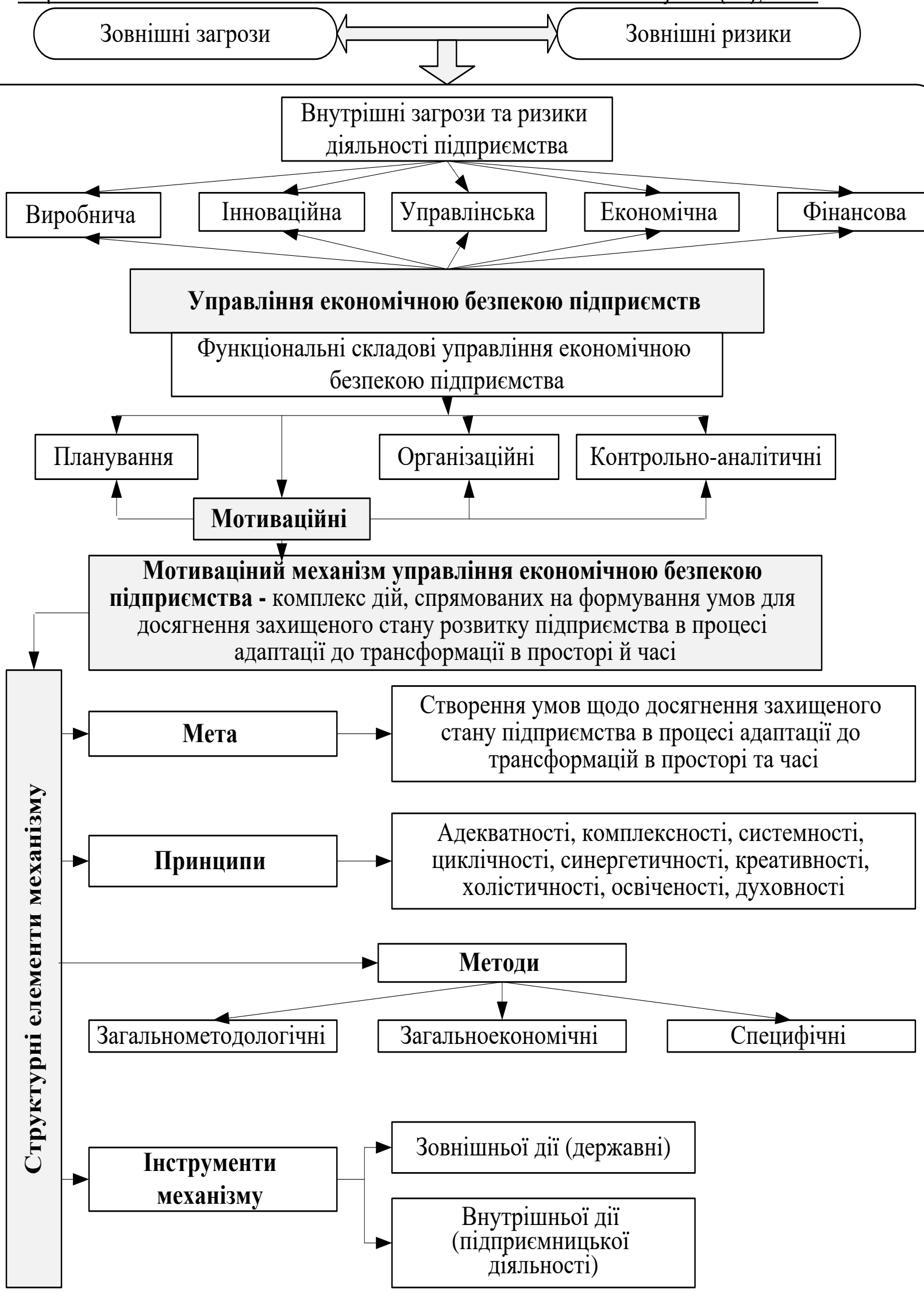

Рис. 2. Мотиваційний механізм управління економічною безпекою підприємства 
Електронне наукове фрахове видання «Адаптивне управління: теорія і практика»

Серія «Економіка»

Випуск 9 (18), 2020

Мотиваційний механізм управління економічною безпекою підприємств можна розглядати як комплекс дій, спрямованих на формування умов для досягнення захищеного стану розвитку підприємства в процесі адаптації до трансформацій в просторі та часі. Центральним функціональним елементом в системі управління економічною безпекою підприємства виступає мотивація, яка спонукає планувати та організовувати види його діяльності на досягнення захищеного стану розвитку підприємства 3 отриманням позитивних економічних показників.

Наряду 3 загальнонауковими принципами управління економічною безпекою підприємств, таких як: ціле полягання; керованість процесом управління; актуальність; системність; науковий підхід; - існує ряд принципів, що притаманні мотиваційному механізму управління економічною безпекою підприємства, до яких можна віднести: принцип безперервності управління, циклічності, адекватності, гнучкості системи управління економічною безпекою підприємства та ін.

Так, принцип безперервності мотиваційного механізму управління економічною безпекою, можна розуміти як процес постійного, безперервного формування умов для захисту розвитку діяльності підприємства.

Відповідно до специфічного принцип циклічності мотиваційного механізму управління економічною безпекою підприємства свідчить, що воно повинно бути здатним до сприйняття циклічних процесів в управлінні в залежності від різних умовах оточення.

Одним 3 основних специфічних принципів мотиваційного механізму управління економічною безпекою підприємства $є$ принцип адекватності. Відповідно до нього, система управління повинна бути здатною до сприйняття різної інформації та можливості вірної іï оцінки для використання.

Розвиток соціально-економічних відносин на всіх рівнях економіки i, насамперед, на мікрорівні, тобто рівні функціонування підприємств, потребує удосконалення мотиваційного механізму управління економічною безпекою на 
Електронне наукове фрахове видання «Адаптивне управління: теорія і практика»

Серія «Економіка»

Випуск 9 (18), 2020

принципах синергетики. Відповідно до нього, виникнення, взаємодія, i

регенерація динамічних об’єктів (підсистем) складніша, ніж елементи (об’єкти) середовища, з якими вони виникають.

Наряду із загальнонауковими методами управління економічною безпекою підприємства, до яких слід віднести й антикризові методи, необхідно зазначити специфічні методи управління, враховуючи інструменти мотиваційного механізму (табл. 1).

Таблиця 1

\section{Інструменти мотиваційного механізму управління економічною} безпекою підприємств

\begin{tabular}{|c|c|c|}
\hline Інструменти & Напрями використання & Результат використання \\
\hline \multicolumn{3}{|c|}{ Державні інструменти (зовнішньої діі) } \\
\hline $\begin{array}{l}\text { Пріоритетність державної } \\
\text { політики }\end{array}$ & $\begin{array}{c}\text { Діяльність окремих галузей } \\
\text { національної економіки }\end{array}$ & $\begin{array}{c}\text { Визначення найбільш } \\
\text { затребуваних галузей } \\
\text { національної економіки для } \\
\text { впровадження інших } \\
\text { державних мотиваційних } \\
\text { інструментів }\end{array}$ \\
\hline сові пільги & \multirow{2}{*}{$\begin{array}{lr}\text { Діяльність } & \text { окремих, } \\
\text { пріоритетних } & \text { галузей } \\
\text { національної } & \text { економіки, } \\
\text { окремих підприємств }\end{array}$} & \multirow{3}{*}{$\begin{array}{c}\text { Можливість отриманні } \\
\text { додаткового фінансування } \\
\text { інноваційної діяльності } \\
\text { підприємств пріоритетних } \\
\text { галузей національної } \\
\text { економіки }\end{array}$} \\
\hline Пільгове кредитування & & \\
\hline Державні гарантії & $\begin{array}{ll}\text { Діяльність } & \text { окремих } \\
\text { підприємств } & \end{array}$ & \\
\hline \multicolumn{3}{|c|}{ Інструменти підприємницької діяльності (внутрішньої дії) } \\
\hline $\begin{array}{l}\text { Креативність мислення особи, } \\
\text { що приймає управлінське } \\
\text { рішення }\end{array}$ & \multirow{4}{*}{$\begin{array}{c}\text { Система управління } \\
\text { підприємством в цілому та } \\
\text { окремих його видів } \\
\text { діяльності }\end{array}$} & \multirow{2}{*}{$\begin{array}{l}\text { Можливість обрання } \\
\text { управлінських рішень } \\
\text { відповідно цілей діяльності } \\
\text { підприємства }\end{array}$} \\
\hline $\begin{array}{l}\text { Інноваційність системи } \\
\text { управління }\end{array}$ & & \\
\hline $\begin{array}{l}\text { Адекватна інформаційність } \\
\text { системи управління }\end{array}$ & & $\begin{array}{lr}\text { Прийняття } & \text { оптимальних } \\
\text { управлінських } \\
\text { стосовно }\end{array}$ \\
\hline $\begin{array}{l}\text { Доступна цифровізація } \\
\text { управління }\end{array}$ & & $\begin{array}{l}\text { Прискорення вибору } \\
\text { оптимального } \\
\text { управлінського рішення }\end{array}$ \\
\hline
\end{tabular}

Як показує досвід країн-лідерів, головною передумовою національного розвитку $\epsilon$ сполученість трьох векторів - державного, громадянського та економічного. В Україні ці вектори навіть не перетинаються. Держава гальмує 
Електронне наукове фрахове видання «Адаптивне управління: теорія і практика»

Серія «Економіка»

Випуск 9 (18), 2020

процес становлення уніфікованих і прозорих правил економічної політики 3 метою збереження контролю i ручного управління розвитком бізнессередовища i, як наслідок, стає заручником приватних інтересів великого капіталу. Бізнес застосовує архаїчні механізми впливу на державні рішення в економічній сфері (тінізація діяльності, кришування, дикий лобізм, шантаж) для досягнення локальних цілей. Симбіоз держави і бізнесу працює на розподіл i випереджаюче споживання національних ресурсів. Роль суспільства залишається пасивною [1].

Тому, найбільш дієвими інструментами мотиваційного механізму управління економічною безпекою підприємств в сучасних умовах вважаємо загальнодержавні. До них слід віднести: податкові пільги й пряме додаткове фінансування (надання інвестиційного податкового кредиту або звільнення повне або часткове - від сплати податку в бюджет, відстрочки або розстрочки податкових платежів у бюджет, надання інвестицій з позабюджетного фонду, участь на паях у фінансуванні програм розвитку підприємств).

Поєднуючи інструменти підприємницької діяльності такі, як: креативність мислення особи, що приймає управлінське рішення; інноваційність системи управління; адекватна інформаційність системи управління; доступна цифровізація управління, - державні інструменти мотиваційного механізму управління економічною безпекою підприємств повинні стати поштовхом до розвитку їх інноваційної діяльності, а саме через $[1,10]:$

- розробку та реалізацію програм або комплексів заходів, спрямованих на формування та розвиток інноваційної інфраструктури, в тому числі виробничотехнологічної інфраструктури (бізнес-інкубаторів, технопарків, інноваційнотехнологічних центрів, інжинірингових центрів, фондів венчурного фінансування, та ін.);

- розробку та впровадження механізмів зниження інвестиційних ризиків в наукомісткі та високотехнологічні проєкти за рахунок державної підтримки 
Електронне наукове фрахове видання «Адаптивне управління: теорія і практика»

Серія «Економіка»

Випуск 9 (18), 2020

заключних стадій досліджень й розробок та доведенням їх результатів до стадії освоєння; це дозволить додатково зацікавити суб'єкти підприємництва в комерціалізації інновацій внаслідок зниження ризиків за цими проєктами (частина ризиків в даному випадку візьме на себе держава);

- формування сприятливого інноваційно-інвестиційного клімату: підвищення привабливості інвестицій, що забезпечують введення нововведень в господарський оборот, тобто процес комерціалізації інновацій (наприклад, слід використовувати засоби амортизаційної політики, систему адресних податкових пільг, пільгове кредитування науково-технічних розробок i часткове фінансування великих проєктів, пільгові умови передачі або надання державного та муніципального майна для інноваційно-активних підприємств); все це має сприяти підвищенню показників ефективності інноваційних проєктів, та посилить мотивацію підприємців до їх реалізації;

- реформування законодавства країни 3 метою стимулювання інноваційної діяльності (наприклад, розвиток інститутів використання та правової охорони результатів наукової та науково-технічної діяльності; створення інституційних умов для розвитку венчурного фінансування); реалізація цього напрямку створить передумови для підвищення рівня правової стабільності внаслідок зниження відповідних ризиків;

- стимулювання формування стійких коопераційних зв'язків та інноваційних кластерів; це посилить наступність стадій наукової діяльності;

- створення умов, що сприяють розширенню експорту наукомісткої продукції та міжнародної технологічної інтеграції; це зміцнить й розширить технологічний обмін 3 іншими країнами, підвисить інтенсивність поширення досягнень;

- створення умов співпраці бізнесу з освітніми установами та урядами, щоб допомогти системі освіти не відставати від потреб ринку праці, компанії повинні фундаментально переосмислити свою роль як споживачів готового 
Електронне наукове фрахове видання «Адаптивне управління: теорія і практика»

Серія «Економіка»

Випуск 9 (18), 2020

людського капіталу, який попередньо формується у школах, закладах професійної освіти, університетах і інших компаніях;

- уряди повинні виходити за рамки системи освіти, зорієнтувавши іiі для сприяння розвитку індивідуальних талантів як людський капітал для подальшого використання в інноваційних проєктах.

Висновок. В результаті дослідження визначено, що в сучасних умовах трансформаційних перетворень національної економіки, підприємства стикаються з рядом проблем, пов’язаних, в тому числі, й $з$ управлінням їх економічної безпеки. Потрібен мотиваційний механізм управління економічною безпекою підприємств, як комплекс дій, спрямованих на формування умов для досягнення захищеного стану розвитку підприємства в процесі адаптації до трансформацій в просторі та часі. Центральним функціональним елементом в системі управління економічною безпекою підприємства виступає мотивація, яка спонукає планувати та організовувати види його діяльності на досягнення захищеного стану розвитку підприємства 3 отриманням позитивних економічних показників.

Наряду 3 загальнонауковими принципами управління економічною безпекою підприємств, такими як: цілеполягання; керованість процесом управління; актуальність; системність; науковий підхід; - в ході дослідження визначено принципи, які притаманні мотиваційному механізму управління економічною безпекою підприємства, a саме: принцип безперервності управління, циклічності, адекватності, гнучкості системи управління економічною безпекою підприємства та ін.

Доведено, що найбільш дієвими інструментами мотиваційного механізму управління економічною безпекою підприємств в сучасних умовах $\epsilon$ загальнодержавні. Поєднанням інструментів підприємницької діяльності таких, як: креативність мислення; інноваційність системи управління; адекватна інформаційність системи управління; доступна цифровізація управління, - 3 державними інструментами мотиваційного механізму управління економічною 
Електронне наукове фрахове видання «Адаптивне управління: теорія і практика»

безпекою підприємств, можна досягти певного розвитку їх інноваційної діяльності.

\section{Використана література}

1. Антикризова стратегія розвитку України: соціально-економічні, фінансові та глобальні виклики: монографія/ Під заг. ред. А.В. Сидорової. Вінниця: ДонНУ, 2016. 328 с.

2. Князевич А.О. Управління інфраструктурним забезпеченням інноваційного розвитку економіки: монографія. Рівне: Волинські обереги, 2018. $362 \mathrm{c}$.

3. Механізм / Вікіпедія. Цитовано: інтернет-ресурс. Режим доступу: http://ru.wikipedia.org/wiki/

4. Мушникова С.А. Конвергенція як системна основа побудови концепції управління безпекою розвитку промислового підприємства. Бізнесінформ. 2019. № 11. C. 336-342.

5. Прохорова В.В., Дем'яненко Т.І. Адаптивне управління інноваційноінвестиційним розвитком підприємств [Текст] : монографія. Харків : НТМТ, 2014. 193 c.

6. Прохорова В.В. Економічний розвиток підприємств: теоретикометодологічний аспект [Текст] : [монографія] Х.: УкрДАЗТ, 2010.521 с.

7. Тімченко О.О., Черепанова В.О. Економічний механізм управління підприємством. Вісник НТУ «ХПI». 2015. № 59 (1168). С. 3-6.

8. Філиппова С.В., Волощук Л.О., Черкасова С.О. Економічна безпека підприємств реального сектору економіки в умовах вартісно-орієнтованого управління: монографія. Одеса: ФОП Бондаренко М.О., 2015. 196 с.

9. Хаустова В.Е., Мушникова С.А. Диверсифікація та інтеграція: домінуюча роль в процесі розвитку підприємств в неотехнологічному середовищі. Економічний вісник «Дніпровської політехніки». 2019. № 4. С. 163-169.

10. Цитовано: інтернет-ресурс. Режим доступу: https://ecouniver.com/2834koyevolyuciya-yekonomicheskoj-sistemy-i-instituta.html EcoUniver

\section{References}

1. Antykryzova stratehiia rozvytku Ukrainy: sotsialno-ekonomichni, finansovi ta hlobalni vyklyky: monohrafiia/ Pid zah. red. A.V. Sydorovoi. - Vinnytsia: DonNU, 2016. $328 \mathrm{~s}$.

2. Kniazevych A.O. Upravlinnia infrastrukturnym zabezpechenniam innovatsiinoho rozvytku ekonomiky: monohrafiia. Rivne: Volynski oberehy, 2018. $362 \mathrm{~s}$. 
Електронне наукове фрахове видання «Адаптивне управління: теорія і практика»

3. Mekhanizm / Vikipediia. Tsytovano: internet-resurs. Rezhym dostupu: http://ru.wikipedia.org/wiki/

4. Mushnykova S.A. Konverhentsiia yak systemna osnova pobudovy kontseptsii upravlinnia bezpekoiu rozvytku promyslovoho pidpryiemstva. Biznesinform, 2019. № 11. S. 336-342.

5. Prokhorova V.V., Demianenko T.I. Adaptyvne upravlinnia innovatsiinoinvestytsiinym rozvytkom pidpryiemstv [Tekst] : monohrafiia. Kharkiv : NTMT, 2014. $193 \mathrm{~s}$.

6. Prokhorova V.V. Ekonomichnyi rozvytok pidpryiemstv: teoretykometodolohichnyi aspekt [Tekst] : [monohrafiia] Kh.: UkrDAZT, 2010.521 s.

7. Timchenko O.O., Cherepanova V.O. Ekonomichnyi mekhanizm upravlinnia pidpryiemstvom. Visnyk NTU «KhPI». 2015. № 59 (1168). S. 3-6.

8. Filyppova S.V., Voloshchuk L.O., Cherkasova S.O. Ekonomichna bezpeka pidpryiemstv realnoho sektoru ekonomiky $\mathrm{v}$ umovakh vartisno-oriientovanoho upravlinnia: monohrafiia. Odesa: FOP Bondarenko M.O., 2015. 196 s.

9. Khaustova V.E., Mushnykova S.A. Dyversyfikatsiia ta intehratsiia: dominuiucha rol $\mathrm{v}$ protsesi rozvytku pidpryiemstv $\mathrm{v}$ neotekhnolohichnomu seredovyshchi. Ekonomichnyi visnyk «Dniprovskoi politekhniky», 2019. № 4. S. 163-169.

10. Tsytovano: internet-resurs. Rezhym dostupu: https://ecouniver.com/2834-koyevolyuciya-yekonomicheskoj-sistemy-iinstituta.html EcoUniver

МУШНИКОВА СВЕТЛАНА

кандидат экономических наук, доцент,

Национальная металлургическая академия Украины, г. Днепр, Украина

\section{КОРСАКОВ ДМИТРИЙ}

кандидат экономических наук, доцент,

Украинская инженерно-педагогическая академия, г. Харьков, Украина

\section{МОТИВАЦИОННЫЙ МЕХАНИЗМ УПРАВЛЕНИЯ ЭКОНОМИЧЕСКОЙ БЕЗОПАСНОСТЬЮ ПРЕДПРИЯТИЙ}

Аннотация. Настоящее время характеризуется кризисными признаками. В результате исследования установлено, что в современных условиях трансформационных преобразований национальной экономики, предприятия сталкиваются с рядом проблем, связанных, в том числе и с управлением их экономической безопасности. Поэтому, нужен мотивационный механизм управления экономической безопасностью предприятий, как комплекс действий, направленных на формирование условий для достижения защищенного состояния развития предприятия в процессе адаптации к 
Електронне наукове фрахове видання «Адаптивне управління: теорія і практика»

Серія «Економіка»

Випуск 9 (18), 2020

трансформациям в пространстве и времени. Центральным функциональным элементом в системе управления экономической безопасностью предприятия выступает мотивация, которая побуждает планировать и организовывать виды его деятельности на достижение защищенного состояния развития предприятия с получением положительных экономических показателей.

Наряду с общенаучными принципами управления экономической безопасностью предприятий, таких как: целеполагания; управляемость процессом управления; актуальность; системность; научный подход; - в ходе исследования определены принципы, которые присущи мотивационному механизму управления экономической безопасностью предприятия, а именно: принцип непрерывности управления, цикличности, адекватности, гибкости системы управления экономической безопасностью предприятия и др.

Доказано, что наиболее действенными инструментами мотивационного механизма управления экономической безопасностью предприятий в современных условиях является общегосударственные. Сочетание инструментов предпринимательской деятельности таких, как: креативность мышления; инновационность системы управления; адекватная информационность системы управления; доступная цифровизация управления с государственными инструментами мотивационного механизма управления экономической безопасностью предприятий, можно достичь определенного развития их инновационной деятельности.

Ключевые слова: экономическая безопасность, управление, предприятие, механизм управления, мотивационный механизм управления.

\title{
MUSHNYKOVA SVITLANA
}

Ph.D in Economics, Associate Professor, National Metallurgical Academy of Ukraine, Dnepr, Ukraine

\section{KORSAKOV DMITRO}

Ph.D in Economics, Associate Professor, Ukrainian Engineering Pedagogics Academy, Kharkiv, Ukraine

\section{MOTIVATIVE MECHANISM FOR MANAGING THE ECONOMIC SECURITY OF ENTERPRISES}

\begin{abstract}
The present time is characterized by crisis signs. As a result of the study, it was found that in the modern conditions of the transformational transformations of the national economy, enterprises are faced with a number of problems associated, including with the management of their economic security. Therefore, a motivational mechanism for managing the economic security of enterprises is needed, as a set of actions aimed at creating conditions for achieving a protected state of enterprise development in the process of adapting to transformations in space and time. The central functional element in the economic
\end{abstract}


Електронне наукове фрахове видання «Адаптивне управління: теорія і практика»

Серія «Економіка»

Випуск 9 (18), 2020

security management system of an enterprise is motivation, which encourages planning and organizing its activities to achieve a protected state of enterprise development with obtaining positive economic indicators.

Along with the general scientific principles of managing the economic security of enterprises, such as: goal-setting; controllability of the control process; relevance; consistency; scientific approach; - in the course of the study, the principles were determined that are inherent in the motivational mechanism for managing the economic security of an enterprise, namely: the principle of continuity of management, cyclicity, adequacy, flexibility of the economic security management system of an enterprise, etc.

It has been proved that the most effective tools of the motivational mechanism for managing the economic security of enterprises in modern conditions are national ones. A combination of entrepreneurial tools such as: creativity of thinking; innovativeness of the management system; adequate information content of the control system; accessible digitalization of management - with state tools of the motivational mechanism for managing the economic security of enterprises, it is possible to achieve a certain development of their innovative activities.

Key words: economic security, management, enterprise, management mechanism, motivational management mechanism. 